\title{
人工衛星画像を用いた有明海の水質解析 WATER QUALITY ANALYSIS IN THE ARIAKE SEA USING ARTIFICIAL SATELLITE IMAGES
}

\author{
大串浩一郎 $1 \cdot$ Thian Yew $\mathrm{GAN}^{2} \cdot$ 荒木宏之 ${ }^{3}$ \\ 1正会員 工博 佐賀大学助教授 理工学部都市工学科（₹840-8502 佐賀市本庄町1番地） \\ 2 Member of CSCE Ph.D. アルバータ大学助教授 土木環境工学科（T6G 2G7 カナダ、エドモントン） \\ 3正会員 工博 佐賀大学教授 低平地研究センター（テ840-8502 佐賀市本庄町1番地）
}

\begin{abstract}
Multiple images of the Landsat-TM were utilized to develop algorithms for retrieving water quality indices of the Ariake Sea. Atmospherically corrected radiance were regressed against the field survey's data, such as transparency, water temperature, turbidity and chlorophyll-a. Results for transparency estimation show that the use of multi-date visible channels as calibration data predicts more accurate and dependable values of water quality at validation stage than the use of single-date calibration ones. Spatial information of water quality in the Ariake Sea can be easily obtained by using proposed algorithms and Landsat images.
\end{abstract}

Key Words : Landsat-TM images, the Ariake Sea, transparency, sea surface temperature, turbidity, chlorophyll-a

\section{1. はじめに}

我が国の多くの都市は河川や湖沼・海域の沿岸部に分 布しており、多かれ少なかれ周辺水域を利用し環境への 負荷を与えている。九州 4 県に囲まれた有明海は、周辺 地域からの影響を受けてきた水域で、逆にまた多くの 人々がこの有明海から恩恵を受けてきた。この海が担っ てきた役割や、将来に向けての環境保全を考える上で、 人間活動か環境へ与える影響を評価し、またこの水域の 今後の水環境をモニタリングしていくことが重要となっ てくる。

ところで、地球観測衛星ランドサットは、これまでさ まざまな分野で広く長期間に渡って利用されてきた息の 長い人工衛星で、水環境に関する分野でも沿岸域や湖沼 の水質問題を研究するため広く用いられてきた。1970年

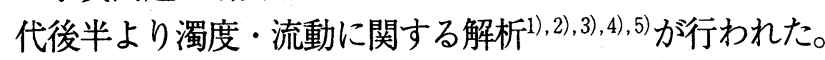
1980年代に入ると単なる濁度や濁水の挙動だけでなく塩 分やクロロフィルaなどの推定を試みる研究 $\left.\left.{ }^{6}\right), 7,8\right)$ が始 まった。水工学へのリモートセンシングの応用について は大西9 が概説している。我が国おいてリモートセンシ ングによるクロロフィルaの推定については水尾ら ${ }^{10)}$ が 検討し、近年はその時系列解析11),12) も行われるように なった。また、水域の流動解析についても数值シミュ
レーションと組み合わせた研究 ${ }^{13)}$ や経時変化による解析 14)も行われてきている。ランドサット以外で水域への適 用例としてはNOAA/AVHRRによる水面温度の推定 $\left.{ }^{15)}, 16\right)$ や JERS-1・MOS-1による河川合流部への適用 ${ }^{17)}$ があるがそ の数は僅かである。ランドサットが広く用いられてきた 理由としては、センサの広範囲のスペクトル特性と約 30 年間という長期に渡って変わらない地球観測を行ってき た事実が挙げられるであろう。

有明海などの広い水域において長期間の情報収集を行 う際に、時間とコストの面から考えると、経済的で効果 的な研究アプローチの 1 つとしてこの衛星リモートセン シングの適用が考えられる。本研究では、この長期に渡 る衛星画像情報と有明海の水質観測資料並びに現地観測 結果を基に回帰解析を行い、有明海の水質評価手法を開 発し、また水環境の長期的な経年変化についても考察を 加えた。

\section{2. 有明海について}

有明海は、図一1に示すように逆字形に屈曲した半閉 鎖性の内湾で、平均水深 $20 \mathrm{~m}$ 、中心線延長 $90 \mathrm{~km}$ 、面積約 $1,700 \mathrm{~km}^{2}$ であり、その規模は東京湾に匹敵する。外海と の連絡は幅約4kmの早崎瀬戸を通してのものがほとんど 


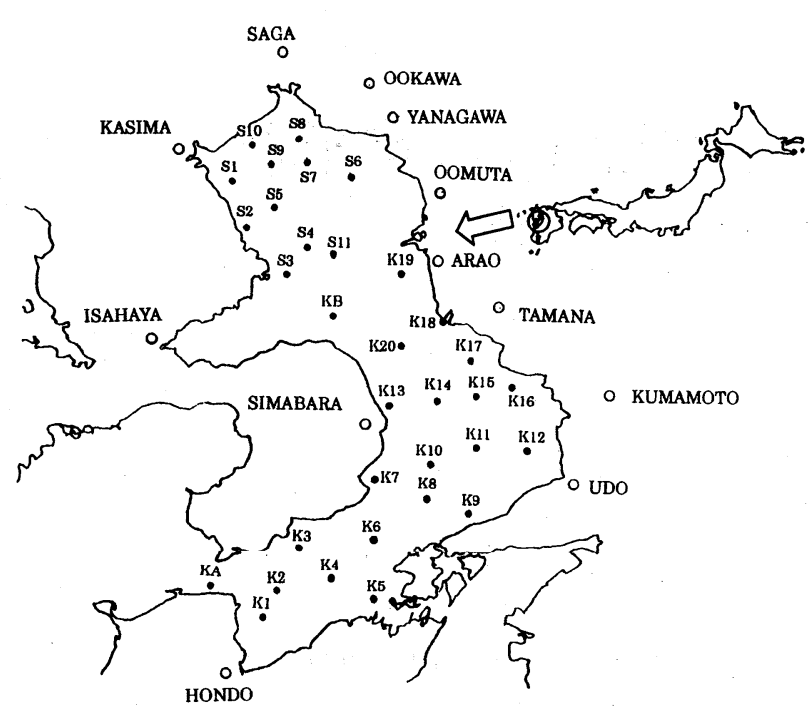

図一1 有明海と水質観測地点

で、南部の八代海とは余り海水交換がないことが分かっ ている ${ }^{18)}$ 。有明海へ流入する主要な一級河川は筑後川な ど8河川であり、上流より土砂等を運んできている。ま た、有明海の潮位差は湾奥部の住之江で $6 \mathrm{~m}$ と我が国最大 である。この両者の相乗作用により有明海沿岸には我が 国の干潟の約 4 割にあたる $220 \mathrm{~km}^{2}$ の広大な干潟が形成さ れ、貴重種を含めて非常に多くの生物の生息場所となっ ている。戦後、有明海周辺の 4 県 (佐賀 ·長崎・福岡 · 熊本) の経済的な発展とともに、有機肥料や栄養物、土 砂などの流入増加により有明海湾奥部などで水質悪化を きたし、水産物漁獲量が大幅に減少している19)。また、 1997年には国の干拓事業により、諫早湾の約 $35.5 \mathrm{~km}^{2}$ が 締め切られている。しかしながら、2001年の海苔不作問 題が起きるとともに諫早湾・有明海は社会問題化してき ている。

陸域からの負荷量や湾内の潮流 - 潮汐が湾内の水環境 に直接影響を及ぼすと考えられるが、物理学的、生物学 的、化学的、あるいはそれ以外の学際領域の共同研究を 進めなければこの海の本当の姿は見えて来ない。人間活 動による水質污染を防ぐためにも、有明海の環境をモニ タリングすることが一つの重要な対策と考えられる。有
明海におけるランドサットによる流況解析としては、渡 辺・瀬口 ${ }^{20)}$ の研究がある。彼らは現地観測データとラン ドサットTMの衛星データを用いて有明海の潮流特性を解 析し、可視域のバンド2で河川からの淡水拡散と海水交 換、バンド4で濁度との関係を、赤外域のバンド 6 で流況 特性を解析している。

\section{3. 解析手法}

本研究では、ランドサットTMデータ並びに図一1のよ うな佐賀県 · 熊本県の有明海における浅海定線調査地点 （33地点）の水質観測資料、佐賀県の赤潮対策調査資料 および補助的に福岡県の浅海定線調査資料と我々自身に よる現地観測結果を用いた。各県の浅海定線調査はほほ 朔望満潮時前後に行われているが、海苔等を対象とした 赤潮対策調査は主に秋から冬、春にかけて実施されてお り、日時や観測地点も浅海定線調査とは一致していない。 これらの調査項目を表一 1 に示す。

まず、衛星画像で推定できる水質項目として、透明度、 水面温度、クロロフィルaなどが考えられるが、クロロ フィルaについては赤潮調査でしか観測していないので、 前の 2 つ項目について浅海定線調査資料を用いて検討 した。ランドサットは16日に 1 回同一地点の地表や海面、 大気から反射・放射されてくる電磁波を観測している。

月に 1 度の浅海定線調査の観測日時と一致し、しかも海 上の雲量が少なく利用可能な衛星画像は数が限られてお り、本研究では表一2に示した 6 つのランドサットTM データのシーンを用いてモデル式を構築することとした。

次にクロロフィルaについては、佐賀県の赤潮対策調 査資料を用いて行ったが、衛星画像取得日時と一致する ものが2000年11月10日のみであることが分かったのでそ のデータを用いることとした。

リモートセンシング解析ソフトウェアとしてPCI社の ImageWorks とGCPWorksを使用した。国土地理院発行の数 值地図25000行政界・海岸線の緯度・経度情報を持った ベクトルデータを用いて、ランドサットTM画像の幾何補 正・画像の切り出しを行った。次に水質観測地点それぞ れについて $30 \mathrm{~m}$ 解像度のピクセルを $4 \times 4$ のウインドウで

表一 1 有明海沿岸各県の水質調査一覧

\begin{tabular}{|c|c|c|c|c|c|}
\hline 県名 & 調査事業名 & 調查時期 & 地点数 & 調 査 項 目 & 開始年 \\
\hline \multirow{2}{*}{ 福岡県 } & 浅海定線調査 & 毎月大潮時 & 10 & 水温, 塩分, 透明度, DO, COD, 栄養塩, プランタト & 1965 \\
\hline & 赤潮監視調査 & 1２回／月 & 4 & 水温, 塩分, 透明度, DO, 栄養塩, 吅フイルa, プランタト & 1985 \\
\hline \multirow[b]{2}{*}{ 佐賀県 } & 浅海定線調査 & 毎月大潮時 & 11 & \multirow{2}{*}{$\begin{array}{l}\text { 水温, 塩分, } \mathrm{pH}, \text { 透明度, D0, 栄養塩, プランタト, } \\
\text { 吅>伅a(赤潮調査時に8点のみ, 1987〜) }\end{array}$} & 1974 \\
\hline & $\begin{array}{l}\text { 有害プランクトン } \\
\text { モ夘ング調査 }\end{array}$ & $10 \sim 3$ 月 & 32 & & 1983 \\
\hline \multirow{2}{*}{ 熊本県 } & 浅海定線調査 & 毎月大潮時 & 22 & 水温, 塩分, 透明度, DO, COD, 栄養塩 & 1974 \\
\hline & 赤潮調査 & 1～3回 /月 & 10 & 水温, 塩分, D0, 栄養塩, 吅口7イa, プラン外 & 1986 \\
\hline \multirow[b]{2}{*}{ 長崎県 } & 浅海定線調査 & $4,8,11,2$ 月 & 14 & 水温, 塩分, プランタト & 1992 \\
\hline & $\begin{array}{l}\text { シャット祙赤潮予 } \\
\text { 察調查 }\end{array}$ & 6〜8月 & 9 & 栄養塩, 吅口倘, DO & 1999 \\
\hline
\end{tabular}


表一2 透明度・水面温度推定アルゴリズム構築のために用いたランドサットTM

画像の各種パラメー夕並びに対応する有明海の満潮位などの状況

\begin{tabular}{|l|c|c|c|c|c|c|}
\hline 衛星観測日 & $\begin{array}{c}\text { 観測時刻 } \\
\text { (日本時 } \\
\text { 間) }\end{array}$ & $\begin{array}{c}\text { 太陽方位角 } \\
(\phi)\end{array}$ & $\begin{array}{c}\text { 太陽天頂角 } \\
(\boldsymbol{\theta})\end{array}$ & $\begin{array}{c}\text { 湾奥部住之江 } \\
\text { における満潮 } \\
\text { 時刻 }\end{array}$ & $\begin{array}{c}\text { 実測による透 } \\
\text { 明度の範囲 } \\
(\mathrm{m})\end{array}$ & $\begin{array}{c}\text { 実測による海水 } \\
\text { 面温度の範囲 } \\
\left({ }^{\circ} \mathrm{C}\right)\end{array}$ \\
\hline $1984 / 9 / 27$ & $10: 24 \mathrm{AM}$ & $139^{\circ}$ & $42^{\circ}$ & $10: 41 \mathrm{AM}$ & $0.8-6.8$ & $24.7-26.6$ \\
\hline $1988 / 4 / 15$ & $10: 23 \mathrm{AM}$ & $126^{\circ}$ & $35^{\circ}$ & $8: 38 \mathrm{AM}$ & $0.8-11.2$ & $13.5-16.8$ \\
\hline $1988 / 5 / 17$ & $10: 24 \mathrm{AM}$ & $113^{\circ}$ & $28^{\circ}$ & $9: 39 \mathrm{AM}$ & $0.8-8.5$ & $17.8-21.1$ \\
\hline $1988 / 11 / 9$ & $10: 24 \mathrm{AM}$ & $152^{\circ}$ & $55^{\circ}$ & $9: 22 \mathrm{AM}$ & $0.3-7.2$ & $16.9-21.4$ \\
\hline $1990 / 11 / 15$ & $10: 13 \mathrm{AM}$ & $149^{\circ}$ & $57^{\circ}$ & $7: 50 \mathrm{AM}$ & $1.0-7.8$ & $16.6-20.1$ \\
\hline $1995 / 5 / 5$ & $10: 01 \mathrm{AM}$ & $112^{\circ}$ & $34^{\circ}$ & $12: 27 \mathrm{AM}$ & & $17.6-19.8$ \\
\hline
\end{tabular}

表一3 ランドサットTMデータの輝度パラメータ並びにLOWTRAN7により得られた大気補正量

\begin{tabular}{|c|c|c|c|c|c|c|}
\hline $\begin{array}{c}\mathrm{TM} \\
\text { Band }\end{array}$ & 波長 $\lambda(\mu \mathrm{m})$ & $\begin{array}{c}\text { Gain }\left(A_{1}\right) \\
\left(\mathrm{W} / \mathrm{m}^{2} / \mathrm{sr} / \mu \mathrm{m}\right.\end{array}$ & $\begin{array}{c}\text { Offset }\left(A_{o}\right) \\
\left(\mathrm{W} / \mathrm{m}^{2} / \mathrm{sr}\right. \\
/ \mu \mathrm{m})\end{array}$ & $\begin{array}{c}\text { Averaged } L_{T}(\lambda) \\
\left(\mathrm{W} / \mathrm{m}^{2} / \mathrm{sr} / \mu \mathrm{m}\right) \\
11 / 15 / 1990\end{array}$ & \multicolumn{2}{|c|}{$\begin{array}{c}L_{R}(\lambda)+L_{A}(\lambda) \text { by Lowtran } 7 \\
\left(\mathrm{~W} / \mathrm{m}^{2} / \mathrm{sr} / \mu \mathrm{m}\right)\end{array}$} \\
\hline 1 & $0.45-0.52$ & 0.602 & -1.500 & 42.047 & 20.580 & 30.210 \\
2 & $0.52-0.60$ & 1.175 & -2.805 & 27.246 & 11.700 & 17.670 \\
3 & $0.63-0.69$ & 0.806 & -1.194 & 16.085 & 5.830 & 9.040 \\
4 & $0.76-0.90$ & 0.814 & -1.500 & 7.265 & 2.030 & 3.300 \\
5 & $1.55-1.75$ & 0.108 & -0.370 & 0.267 & 0.065 & 0.094 \\
6 & $10.5-12.5$ & 0.056 & 1.238 & 7.893 & 7.050 & 7.530 \\
7 & $2.08-2.35$ & 0.057 & -0.150 & 0.012 & 0.007 & 0.012 \\
\hline
\end{tabular}

平均化して不必要なノイズや位置の誤差などをできる だけ除去した。

最後に、これらの幾何補正などの補正を施した画像 デー夕を各波長バンド毎に気象デー夕をもとに LOWTRAN7という大気補正プログラムを用いて大気補正 を行い、各バンド毎の正確なスペクトル輝度情報を取 得した。LOWTRAN7に入力した気象データは、佐賀・福 岡・長崎・熊本 4 県における風速、降水量、気温、視 程などである。

\section{4. 衛星データの大気補正}

Tassan ${ }^{7)}$ は、ランドサットTMPNIMBUS7 のCZCSデータ と水質パラメータ（例えば濁度、透明度、SS、クロロ フィルなど）を定量的に関係づけることが可能である ことを示した。理論的には、水面からの放射輝度の強 さや量は水中に存在する懸濁物質の量に影響される。 その理由は、懸濁物質が水中に含まれることで海水の 反射特性が変化するからである。また、熱赤外バンド のランドサットTMの6チャンネルは水面温度と密接に関 係することも見いだされている。

しかしながら、衛星のセンサに到達する電磁波の輝 度情報は海水面の情報だけを含む訳ではない。センサ に到達する波長 $\lambda$ の電磁波の放射輝度 $L_{T}(\lambda)$ は、海水面 の輝度 $L_{\mathbb{W}}(\lambda)$ と大気中の空気分子によるRayleigh散乱量
$L_{R}(\lambda)$ 並びに分子より大きいエアロゾルによる散乱量 $L_{A}(\lambda)$ の和で表される4)。

$$
L_{T}(\lambda)=L_{W}(\lambda)+L_{R}(\lambda)+L_{A}(\lambda)
$$

複数の日時の衛星画像を扱う際には大気補正が非常 に重要になってくる。なぜならば、水質パラメー夕は 海水面からの放射輝度 $L_{W}(\lambda)$ に関係しており、センサに 到達する全放射輝度 $L_{T}(\lambda)$ とは異なるからである。その 差 $L_{R}(\lambda)+L_{A}(\lambda)$ は、大気の状態によって変化する、す なわち画像ごとに異なるので気象状況に応じてそれぞ れ補正する必要がある。

本研究では、Knetzysら ${ }^{21)}$ の大気モデルLOWTRAN7を用 $\omega て L_{R}(\lambda)+L_{A}(\lambda)$ を見積もった。表一3は、中緯度の 海洋におけるエアロゾルに対する大気デー夕を元に LOWTRAN7により見積もった1990年11月15日及び1988年5 月17日の有明海における $L_{R}(\lambda)+L_{A}(\lambda)$ の値を示してい る。LOWTRAN7では大気からの熱放射（大気放射）と大 気によって散乱される太陽放射（パスラジアンス）を 計算する。前者は可視域、近赤外並びに熱赤外域

(0.45 2.35 $\mu \mathrm{m}$ の範囲) において無視できるほど小さ いことが分かったが、後者では最大 $30 \mathrm{Wm}^{-2} \mathrm{sr}^{-1} \mu \mathrm{m}^{-1}$ 程度 に達することが分かった（表一3）。6枚の画像全てで バンド 1 におけるセンサに到達する全放射輝度は $50 \mathrm{Wm}^{-2}$ 
表一４クロロフィルa推定アルゴリズム構築並びに 3 つの水質の経時変化を見るため

7つの衛星デー夕の大気補正量をLOWTRAN7で計算した結果（単位W $/ \mathrm{m}^{2} / \mathrm{sr} / \mu \mathrm{m}$ )

\begin{tabular}{|c|r|r|r|r|r|r|r|}
\hline TM Band & $1988 / 4 / 15$ & $1995 / 5 / 5$ & $1997 / 4 / 24$ & $1998 / 4 / 27$ & $1999 / 4 / 14$ & $2000 / 5 / 2$ & $2000 / 11 / 10$ \\
\hline \multirow{2}{*}{1} & 26.7 & 26.6 & 27.2 & 28.0 & 27.0 & 28.2 & 20.6 \\
\cline { 2 - 8 } & 46.8 & 47.7 & 48.2 & 49.3 & 47.8 & 49.9 & 33.7 \\
\hline \multirow{2}{*}{2} & 15.4 & 15.2 & 15.8 & 16.2 & 15.6 & 16.3 & 11.7 \\
\cline { 2 - 8 } & 36.8 & 37.6 & 37.7 & 38.7 & 37.4 & 39.1 & 25.7 \\
\hline \multirow{2}{*}{3} & 8.16 & 7.97 & 8.44 & 8.58 & 8.37 & 8.72 & 6.18 \\
\cline { 2 - 8 } & 29.8 & 30.0 & 30.03 & 31.3 & 30.0 & 31.5 & 21.2 \\
\hline \multirow{2}{*}{4} & 2.78 & 2.65 & 2.98 & 2.94 & 2.94 & 3.04 & 2.12 \\
\cline { 2 - 8 } & 17.3 & 17.7 & 17.5 & 18.2 & 17.4 & 18.3 & 13.4 \\
\hline \multirow{2}{*}{5} & 0.0947 & 0.074 & 0.136 & 0.0991 & 0.134 & 0.118 & 0.0798 \\
\cline { 2 - 8 } & 4.14 & 4.21 & 4.12 & 4.32 & 4.09 & 4.31 & 3.09 \\
\hline \multirow{2}{*}{6} & 7.37 & 7.30 & 7.23 & 7.66 & 7.12 & 7.44 & 7.18 \\
\cline { 2 - 8 } & 7.37 & 7.30 & 7.23 & 7.66 & 7.12 & 7.44 & 7.18 \\
\hline \multirow{2}{*}{7} & 0.015 & 0.0095 & 0.0253 & 0.016 & 0.0249 & 0.0207 & 0.0138 \\
\cline { 2 - 8 } & 1.24 & 1.28 & 1.24 & 1.29 & 1.23 & 1.29 & 0.926 \\
\hline
\end{tabular}

$\mathrm{sr}^{-1} \mu \mathrm{m}^{-1}$ を超えていないので、結局、ランドサットTMセ ンサのバンド 1 が受け取るスペクトル放射輝度の中に 海水中の情報は 40～50\%しか含まれていないことを意味 する。

同様にして、クロロフィルa推定アルゴリズム構築の ための衛星データ並びに上記透明度、水面温度とクロ ロフィルaの経時変化を見るための他の衛星データにつ いても大気補正のためLOWTRAN7による計算を行った。 結果を表一 4 に示す。各バンド毎に上段が大気による 影響を含むスペクトル輝度 $L_{R}(\lambda)+L_{A}(\lambda)$ で、下段がセ ンサが受け取るスペクトル輝度の全量である。この差 が海水面の情報を示すことになる。この結果を参照す るとバンド 6 を除いて他の 6 つのバンドでは波長が長 くなるにしたがって大気の影響の割合が小さくなって いるのが分かる。バンド 6 については残念ながら全て が大気の影響を受けているので水質推定には利用でき ないことも判断できる。後の節に示すように、水温の 推定にはバンド 6 のデー夕を用いるので、水温の時系 列変化についてはこれらの衛星画像からは推定できな いことが分かった。

\section{5. 水質データと回帰解析}

潮汐の効果は、得られる水質データや画像データの 精度に影響を与え得るので、ランドサットTM画像が取 得された日における有明海湾奥の住之江で潮位変化を 調べた。 表一2に示すようにこの地域のランドサット 衛星画像はほとんど全て午前10:00〜10:30頃取得され ていることが分かる。有明海の干潮や満潮時とこの時 間が重なれば潮流は非常に小さくなり衛星画像が捉え る各観測地点の輝度情報との時間差を小さくとること が出来て理想的である。また、この時間に全ての水質 観測がなされればさらに完全を期すことが出来るが、
有明海の水域の広さを考えるとそれは不可能である。 事実、佐賀県、熊本県の水質観測では、毎月大潮の満 潮時に水質観測を行っているが、全ての観測地点で一 斉に観測を行っている訳ではないので数時間のずれが 起きるのが普通である。表一2によれば、1984年9月 27 日、1988年5月17日及び同年11月9日は余り潮汐の影響 を受けていないが、一方、1988年4月15日と1990年11月 15日は少し潮汐の影響を受けていることが分かる。

\section{（1）透明度（transparency, Secchi Disk Depth ;}

SDD)

透明度は、水がどれだけ透明であるかを表すために 水面から光がどこまで届くのかという長さの単位を用 いる。水中の懸濁物質の存在によりこの量は減少して いく。理論的には、人工衛星が受け取る放射量は透明 度に反比例するはずであり、両者の間の経験的な関係 を求めることが可能である。

大気補正を施したスペクトル放射輝度（各バンド毎 の放射輝度）と透明度の相関を取ると、特にバンド 1 から 3 との相関が高いことが分かった。さまざまなア ルゴリズムを線形回帰解析により試した結果、次式の 評価アルゴリズムが最適な結果を与えることが分かっ た。

$\sqrt{S D D}=1.8041+0.1472 \times T M_{1}-0.2652 \times T M_{2}+0.1076 T M_{3}$

ここで、 $S D D$ は透明度 $(\mathrm{m})$ を、 $T M_{1}, T M_{2}, T M_{3}$ はバ ンド 1 から 3 の大気補正済みのスペクトル放射輝度を 表す。

キャリブレーション段階で1984/9/27，1988/4/15, 
1988/5/17，1988/11/9の 4 つの時期の大気補正済みの 衛星データを用い、その結果を別の時期の透明度推定 に利用できるかどうかを検証した。その結果、相関係 数 0.80 、バイアス $1.75 \%$ とかなり高い精度に高められる ことが分かった。すなわち、異なる日時の衛星画像で あっても、適切に大気補正がなされれば同時にキャリ ブレーション時に組み込むことで、季節的な変動も取 り込まれた普遍的なアルゴリズムが求まる可能性があ るということが明らかとなった。

(2) 海水面温度(Sea Surface Temperature ; SST)

海水面温度 (SST) は気象に大きな影響を与えるパラ メータで、世界中で気象学者によって詳細なモニタリ ングがなされている。近年、NOAA-AVHRRデー夕による 地球規模の海水面温度マップが作成されている。また、 有明海においても同様に海水面温度をNOAA-AVHRRデー 夕により評価する試みもなされている16)。ただし、NOAA の空間分解能は $1.1 \mathrm{~km}$ と粗く、ランドサットTMが分解能 $30 \mathrm{~m}$ (ランドサット7号はパンクロマチックで $15 \mathrm{~m}$ の空間 分解能を持っている）であることを考慮すると、再者 の使い分けを考えなければならない。

本研究では、ランドサットTMの各バンド（特に熱赤 外バンド（バンド6）の相関が高い）を用いて有明海の 海水面温度を評価することを試みた。

SSTについては、最も相関が高かったランドサット TMのバンド6のみを用いて以下の回帰式の係数を求め た。

$$
\left(S S T-\mu_{S S T}\right)=-0.5742 \times\left(T M_{6}-\mu_{T M 6}\right)
$$

ここで、 $\mu_{S S T}, \mu_{T M 6}$ はそれぞれ、海水面温度の平均值並

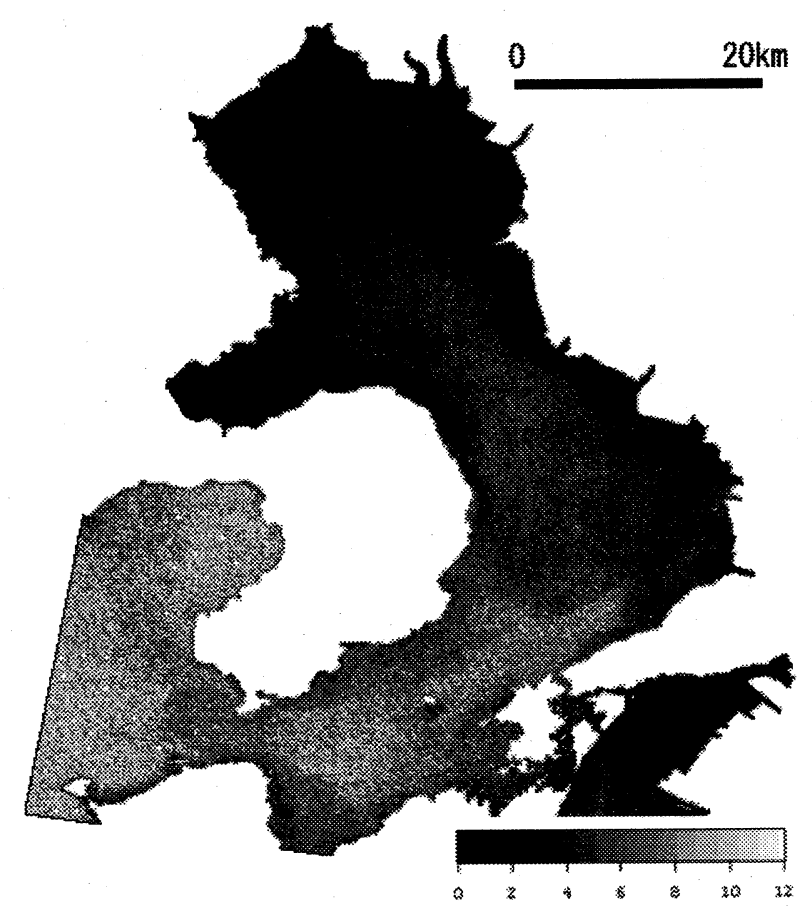

図一2 透明度推定図（1988年4月15日）
びにバンド 6 の大気補正済みの放射輝度データの平均 值である。平均值からの偏差をとった理由は、衛星 データのみからでは海水面温度の絶対值を十分に評価 できなかったためである。キャリブレーションで1984 年9月 27 日と 1995 年5月5日のデー夕を用い、検証段階 で1990年11月15日の海水面温度の推定に適用した所、 相関係数 0.41 、バイアス $0 \%$ を得た。相関係数について はまだ不十分な結果であるが、海水面温度の推定をあ る程度の精度で行うことが可能であることが分かった。

\section{（3） クロロフィルa(Chlorophyll-a; Chl-a)}

クロロフィルはa, b, c, dと存在するが、全ての藻類に 含まれるのがクロロフィルaである。植物プランクトン 濃度の指標としてこのクロロフィルa濃度がよく用いら れる。クロロフィル濃度の大きさにより水面から射出 する光の波長分布は異なるが、TMのバンド 2（波長 0.52-0.60 $\mu \mathrm{m})$ 周辺においてはその変化が少ないこと が分かっている。このことを利用して、上向き照度が クロロフィル濃度に依存する波長域のバンドとバンド 2 を組み合わせてクロロフィル濃度を推定する試みが なされてきた10),11),12)。

本研究では、いくつかの組み合わせによるクロロ フィルa濃度の推定方法を検討したが、キャリブレー ションに利用できる衛星画像が少なかったため相関係 数が 0.408 と非常に低かった。得られた回帰式は以下の 通りである。

$$
\log (C h l-a)=2.34-0.33\left(T M_{2} / T M_{4}\right)
$$

今後、現場における実測などを増やして、より精度の 高いモデル式を構築する必要がある。

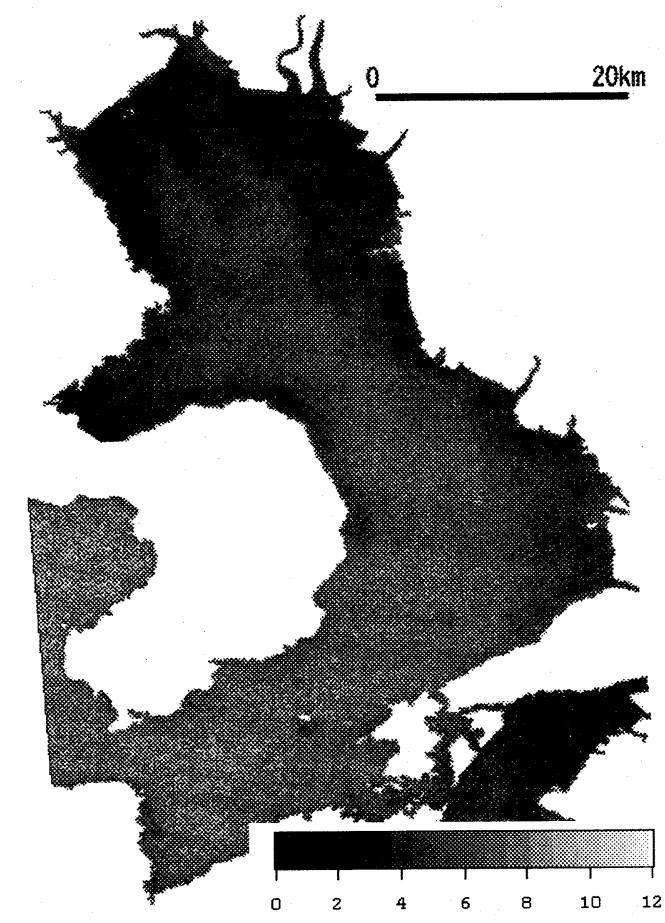

図一3 透明度推定図（2000年5月 2日） 


\section{6. 有明海における水質の時系列変化について}

以上のようにしてランドサットTMデータと水質観測 資料を用いて水質評価アルゴリズムを構築し、有明海 の水質の時系列変化について解析を行った。式(2),(4)を 用いて透明度とクロロフィル濃度を推定し、その時系 列変化を検討したが、透明度についてその結果の一部 を示したのか図一2、図一3である。前者は1988年4月15 日の透明度分布推定図、後者は 2000 年 5 月 2 日の図であ る。両者の潮の時期は月齢28日と27.4日でほぼ等しく、 衛星画像取得時刻の $10: 30$ 前後は最大下げ潮の約 1 時間 前である。全体的な透明度の大きさは 2000 年の方が高 いことと、1988年の下げ潮の流れによる底泥の巻き上 げなども大きいことが推測される。両者の観測日以前 の降水量や風、気圧などの影響も考慮しなければなら ないが、そのような自然条件以外に人間活動による影 響も否定はできないと考えられる。

\section{7. 結論}

地球観測衛星ランドサットのTMデータと水質観測資 料を用いて有明海の透明度、海水面温度、クロロフィ ルa濃度の評価アルゴリズムを構築することができた。 透明度については、複数の日時の衛星画像をキャリブ レーションに用いることで推定精度を大幅に向上でき ることが分かった。また、衛星画像を用いることで有 明海水環境の広域の経時変化を定性的・定量的に把握 することが可能であることが明らかとなった。

謝辞: 本研究は、平成13年度文部科学省科学研究費補 助金基盤研究 (C)（課題番号13650572）の援助のもとで 行われた。また、本研究で用いたランドサットTMデー 夕は宇宙開発事業団より研究用として提供されたもの である。さらに、有明海の水質観測資料は、佐賀県有 明水産振興センター、熊本県水産研究センター並びに 福岡県有明海研究所より提供していただいた。あわせ て感謝の意を表する。

\section{参考文献}

1) Abiodun, A. A.: Satellite survey of particulate distribution patterns in Lake Kainji, Remote Sensing Environ., 5, pp.109-123, 1976.

2) 大西外明、田中聰太郎：Landsatによる急傾斜湾内密度流フ ロントの観測と安定性に関する考察、土木学会論文報告集、 No.292、pp.53-63, 1979.

3) Carpenter, D. J., and Carpenter, S. M.: Modeling inland water quality using Landsat data, Remote Sensing of Env., 13, pp.345 $352,1983$.

4) Aranuvachapun, S. and LeBlond, P. H.: Turbidity of coastal water determined from Landsat, Remote Sensing of Env., 14, pp.113-132, 1984.

5) 宇多高明、古川博一、竹渕勉：ランドサット・航空機・船
の同時観測による沿岸海域特性の把握、第31回海岸工学講 演会論文集、pp.690-694, 1984.

6) Khorram, S.: Development of water quality models applicable throughout the entire San Francisco Bay and delta, Photogram. Eng. Remote Sensing, 51, pp. 53-62, 1985.

7) Tassan, S.: Evaluation of the potential of the thematic mapper for marine application, Int. J. Remote Sensing, 8, pp.1455-1478, 1987.

8) 大西外明、河合弘泰：ランドサットTMデー夕による河口流 出の解析法の提案－新宮川への適用、土木学会論文集、 No.452/II-20, pp.11-20, 1992.

9) 大西外明：水工学とリモートセンシング、土木学会論文集、 No.393/II-9, pp.9-20, 1988.

10) 水尾寛己、二宮勝幸、雮石雅美、多賀保志、安岡善文 : TMデータによる東京湾のクロロフィルa量の観測の検討一 中間赤外域における水質情報抽出可能性一、日本リモート センシング学会誌、Vol.11,No.3, pp.135-139, 1991.

11）鈴木三貴子、武田健一、岩下圭之他：TTMデータによる 東京湾の水質環境りモートセンシング、土木学会第54回年 次学術講演会講演概要集、共通セッション、pp.16-17, 1999.

12) 水出寛之、岩下圭之他：LANDSAT MSS/TMデータを利用 した内湾のChlorophyll-a分布の時系列評価、土木学会第56回 年次学術講演会講演概要集、第IVセッション、pp.394-395, 2001.

13）兵頭竜二、後藤恵之輔：衛星リモートセンシングによる閉 鎖性湾の流動シミュレーションの検証、水工学論文集、第 43巻、pp.851-856、1999.

14) 藤井壽生、工藤勝輝、岩下圭之他：印旛沼の濁度分布経時 变化から判読した流動化メカーズム解析-LANDSAT TTM データによるー、日本リモートセンシング学会誌、Vol.20, No.3, pp.71-84, 2000.

15) 菊川浩行、木下紀正他：NOAA/AVHRRによる鹿児島湾表 面水温の季節変化の解析、日本リモートセンシング学会誌、 Vol.16, No.3, pp.35-45, 1996.

16) 福士大介、風間聡、沢本正樹 : NOAA/AVHRRデータを用 いた有明海周辺の熱環境解析、土木学会論文集、No.677/II55,pp.163-174, 2001.

17) 田中修三、西川肇、岩下圭之他：衛星データによる河川合 流区間のリモートセンシング、日本リモートセンシング学 会誌、Vol.16, No.5, pp.14-22, 1996.

18）気象庁: 有明海・八代海の海象調查報告書、 1974 .

19）菅野徹: 有明海、東海大学出版会, 1981.

20) Watanabe, K. and Seguchi, M.: Study on oceanic phenomena in the shallow area of Ariake Sea by remote sensing, II, Observation of flow regime by Landsat 5 TM data, Bull. Fac. Agr. Saga University, 65, pp.53-59, Saga Japan, 1988.

21) Kneizys, F. X. et al.: User code to LOWTRAN 7. AFGL-TR88-0177 Environmental Research papers, No. 1010, US Department of Defense, Air Force Geophysics Laboratory, Optical Physics Division, 137, 1988.

（2001.10.1受付） 